\title{
NOTA PRÉVIA \\ SUBSÍDIOS TÉCNICO-CIENTÍFICOS PARA UM PROGRAMA DE EDUCAÇÃO AMBIENTAL
}

A partir da implantação de um Programa de Educação Ambiental como uma das diretrizes básicas de atuação da CPRN - Coordenadoria da Pesquina de Recursos Naturais - , alguns técnicos do Instituto Geológico apresentaram sugestões para se desenvolver um projeto, que teria por finalidade integrar o Instituto nessa diretriz e apresentar contribuições pará dar melhores esclarecimentos quanto à Educação Ambiental. Neste sentido, está sendo aproveitado todo um acervo de conhecimento e vivência pessoal e profissional dos técnicos envolvidos na proposta em pauta.

A proposta de trabalho é preliminar; pretende-se estabelecer uma linha de pesquisa sistemática em Educação Ambiental. Assim, a mesma está sujeita a ampliações posteriores, embora já haja certos dimensionamentos. Por tratar-se de uma pesquisa sistemática, é necessário esclarecer que ela poderá ter vários prazos: curto, médio e longo, sendo obtido em cada prazo produtos que estarão de acordo com as prioridades estabelecidas pelos acontecimentos ambientais. Esses produtos poderão ser de carátcr didático, informativo, conceitual etc.

No âmbito da diretriz de Educação Ambiental proposta pela CPRN, o Instituto Geológico pode ser considerado como um universo próprio no contexto das demais instituições que integram essa linha programática e que por sua vez representam outros universos. Juntos à CPRN, eles se projetam de forma hierárquica a nível administrativo, técnicocientífico e sócio-econômico.
Luci Hidalgo NUNES* Manoel Carlos de OLIVEIRA* Maria da Saudade A.S. MARANHÃO* Maria Helena de Almeida MELLO*

O corpo de funcionários dentro do Instituto Geológico pertence a uma comunidade ao mesmo tempo técnicocientífica e administrativa e, por sua vez, faz parte da sociedade; ao se movimentar de uma comunidade para outra, assume vivências diferentes e interpretações específicas em relação à questão do meio ambiente. É necessário estudar essas vivências, no sentido de se conseguir uma atitude integrada à realidade ambiental, mas que possa contribuir para a promoção desse ambiente, tentando dar soluções adequadas ao potencial preestabelecido pelo mesmo.

Dentro da perspectiva profissional, é preciso ter-se em mente que, embora se manipule conceitos de ordem variada, eles estão dentro da questão ambiental. Ao se trabalhar com o planejamento do espaço, é imprescindivel levar em consideração o impacto e possiveis transformações que a área irá sofrer. Pode-se lembrar o exemplo da mineração, que imprime modificações negativas na paisagem; o papel dos técnicos em meio ambiente é fazer propostas, de modo que a referida área possa ser recuperada.

A idéia de se desenvolver o presente trabalho, surgiu da necessidade de se refletir a sério sobre a Educação Ambiental e como ela poderia tornar-se um meio eficaz para a defesa do meio ambiente. O intuito é realizar a pesquisa através da percepção do ambiente e como se dá a interação Homem/ambiente, profissional/ambiente e ainda, como cada um poderia atuar como agente educador.

* Instituto Geológico - Caixa Postal 8772 - 01000 - São Paulo, SP, Brasil. 
Rev. IG, São Paulo, 5(1/2):51-53, jan./dez. 1984

\section{A equipe de trabalho apresenta as seguintes propostas:}

- Desenvolver pesquisas visando à caracterização dos fundamentos para a Educação Ambiental;

- Contribuir para uma melhor integração interinstitutos, com a universidade e com a sociedade de maneira geral;

- Integrar áreas da ciência e da tecnologia que se proocupam com a problemática ambiental;
- Viabilizar ação institucional adequada quanto à Educação Ambiental;

- Levantar o nível de conscientização e conhecimento dos indivíduos no que concerne à Educação Ambiental;

- Promover atividades ligadas à divulgação da questão ambiental;

- Criar uma sistemática de pesquisa em Educação Ambiental;

- Criar um núcleo interno de Educação Ambiental. 